\title{
Qualitative Analysis of Metacognition Ability and Creativity Thinking with Jigsaw Cooperative Learning Model
}

\author{
Ratu Natalia Perangin-angin \\ Department of Mathematics Education \\ Postgraduate Program \\ Universitas Negeri Medan \\ Medan, Indonesia \\ ratu.natalia@gmail.com
}

\author{
Bornok Sinaga \\ Department of Mathematics Education \\ Postgraduate Program \\ Universitas Negeri Medan \\ Medan, Indonesia
}

\author{
Edi Syahputra \\ Department of Mathematics Education \\ Universitas Negeri Medan \\ Medan, Indonesia
}

\begin{abstract}
This research is a qualitative descriptive study. This research is a type of research that aims to describe the quality of metacognition abilities and the creative thinking ability of students who get a jigsaw type cooperative learning model. This research was conducted in Grade VIII An Pancur Batu Middle School Methodist, amounting to 38 people. Based on the results of the test of metacognition ability and creative thinking ability tested to students the subject will be taken to be interviewed. The criteria for taking the subject is to use 3 criteria, namely based on indicators of student ability, answer errors, and unique answers. Through the indicator glasses the student answer sheets are grouped into three categories of answers, namely (1) answer sheets of highly capable students; (2) answer sheets for students with moderate abilities; (3) answer sheets for low-ability students. Based on the results of the students' mathematical creative thinking ability test, it was found that the very low category was $15.79 \%$, the low category was $50.00 \%$, the moderate category was $18.42 \%$, the high category was $10.53 \%$, the very high category was $5.26 \%$. While the results of the metacognitive ability test were obtained that the category was very low at $13.16 \%$, as low as $\mathbf{7 1 . 0 5 \%}$, medium as much as $\mathbf{1 0 . 5 3 \%}$, high as much as $\mathbf{5 . 2 6 \%}$, and very high as $0.00 \%$.
\end{abstract}

Keywords-metacognitive ability, creativity thinking, cooperative learning model, cooperative Jigsaw type

\section{INTRODUCTION}

Mathematics is a universal science that underlies the development of modern technology, has an important role in various disciplines and develops human thought power. The progress of science and technology requires a person to be able to master information and knowledge. These abilities require critical, systematic, logical, and creative thinking. According to Weittgenstein, one of the educational programs that can develop the ability to think critically, systematically, logically, and creatively is mathematics [1]. Mathematics as one of the basic sciences, both its applied aspects and its reasoning aspects have a very important role in the mastery of science and technology. Based on the above expressions it is concluded that mathematics is a very important basic science mastered for everyone who can be applied and useful in everyday life.

The development of creative thinking ability is very important because this ability is one of the abilities desired in the world of work. So there is no doubt that creativity is a determinant of individual success in facing increasingly complex life challenges. Ervync states that creativity plays an important role in the full cycle of mathematical thinking [2] The latest discoveries are inseparable from the individual's creative thinking abilities. Creativity is an embodiment of the individual, a creative work as a result of the creativity of a person that creates its own satisfaction in the person. According to Treffinger that creative thinking emphasizes aspects of fluency, flexibility, originality and elaboration [2].

In addition to creativity, metacognition abilities are also important for students to have. Metacognition has the advantage that a person tries to contemplate the way of thinking or contemplating the cognitive process he does. Metacognition is also a process by which a person thinks about thinking in order to develop strategies to solve problems. Metacognition as thinking about thinking, metacognition is the ability where the object of thinking is the thought process that occurs in oneself [3]. Students are said to have metacognitive abilities if in problem solving students are able to fulfill the following stages: 1) developing an action plan, 2) organizing or monitoring completion actions, and 3 ) evaluating completion actions [4].

Based on the results of preliminary observations made by researchers at SMP Methodist-An Pancur Batu in grade VIIIGoodness, it shows that students' creative thinking and metacognition abilities are still low. This can be seen from the results of diagnostic tests provided. One of the results of classroom observations shows that teachers still often use learning methods based on teacher centered activities and students are only accustomed to listening, completing exercises given by the teacher, then discussed and so on until the end of the lesson. So it is not accustomed to practice creativity and metacognition in learning activities. 
Based on these conditions, teacher skills are needed in the selection of learning models that can make students active in participating in learning activities so that students can construct their ideas and can improve their creative thinking and metacognition. One of them is applying cooperative learning in teaching and learning activities. Jhonson and Jhonson said that "the atmosphere of cooperative learning results in higher achievement, a more positive relationship than psychological adjustment that is better than an atmosphere of learning that is full of competition and separates students" [5].

According to Lie, the tigsaw type cooperative model is one type or flexible cooperative model [5]. A lot of research has been done relating to cooperative learning on the basis of Jigsaw. The research consistently shows that students involved in learning this Jigsaw cooperative model get better achievements, have better attitudes and are more positive towards learning, in addition to respecting the differences and opinions of others. Researchers chose to use the Jigsaw cooperative learning model in terms of strengths, which teach students to believe in the teacher and more trust in their own ability to think to find information from other sources and learn from other students.

Based on the problem that has been described, the objectives of this study are: 1) Knowing the students 'metacognition abilities by applying the Jigsaw cooperative model, 2) Knowing the students' creative thinking abilities by applying the Jigsaw cooperative learning model, 3) Knowing the difficulties experienced by students in cognitive cognition , and 4) Knowing the difficulties experienced by students in mathematical creative thinking.

\section{LITERATURE REVIEW}

\subsection{Creative Thinking Ability}

Creativity is the result of creative thinking. Creativity is a person's ability to produce any composition, product or idea that is basically new and previously unknown to its maker. Creativity can be seen as a product of creative thinking, while creative activities are learning activities that are directed to encourage or bring up student creativity. As stated by Pehkonen that creativity is not a characteristic only found in artists and scientists, but it is also a part of everyday life [6]. Creative thinking is associated as a process in creativity. Creative process refers to individual efforts to produce creative solutions or products.

Pehkonen states that creativity is a performance produced by an individual so that it becomes something new or unexpected [6]. Correspondingly, Baron states that "Creativity is the ability to bring something new into existence" [6]. From these statements it can be seen that creativity is the ability to create something new, both in the form of ideas and real work that is relatively different from what has been there before.

A student's mathematical creativity when solving a given problem by meeting all the indicators of creative thinking. Some experts put forward indicators of creative thinking ability, including those who put forward indicators of creative thinking ability such as Torrance et al. According to Torrance indicators of creative thinking ability are: 1) Fluency, 2) Flexybility, 3) Originality, and 4) Elaboration [7].

The several criteria for the answers to the indicators put forward by some experts in Table 1 below [8].

TABle 1. CRiteria of ANSWER Process BASEd ON INDiCATOR OF CREATIVE THINKING

\begin{tabular}{|c|c|}
\hline Indicator & Criteria of Answer Proccess \\
\hline Fluency & $\begin{array}{l}\checkmark \text { Make lots of ideas / ideas in problem solving } \\
\checkmark \text { Provide many answers in problem solving }\end{array}$ \\
\hline Flexibility & $\begin{array}{l}\checkmark \text { Generate various problem solving variations } \\
\checkmark \text { See a problem from different points of view and present } \\
\text { a concept in different ways. }\end{array}$ \\
\hline Originality & $\begin{array}{l}\checkmark \text { Give new or unusual ideas to solve problems } \\
\checkmark \text { Make unusual combinations of parts or elements } \\
\text { whether in language, ideas or ways }\end{array}$ \\
\hline Elaboration & $\begin{array}{ll}\checkmark & \text { Developing or enriching ideas } \\
\checkmark & \text { Add or detail an idea so as to improve the quality of the } \\
\text { idea }\end{array}$ \\
\hline
\end{tabular}

Based on the description above by considering the ease in its application, then in this study students are said to have mathematical creativity when able to solve problems with fluency, flexibility, originality, and elaboration.

\subsection{Metacognitive Ability}

Metacognition refers to higher order thinking which involves active control over the cognitive processes engaged in learning. Activities such as planning how to approach a given learning task, monitoring comprehension, and evaluating progress toward the completion of a task are metacognitive in nature [9]. But on the other hand, Papaleontiou-Lonca states metacognition is something about one's own thinking, thinking about thinking and responding to one's own thoughts by controlling and regulating it [10].

Simply put, metacognition is thinking about thinking [11]. Metacognition is thinking about our thinking and it comprises of the following three important aspects: knowledge about our own thought processes, control or self-regulation, and belief and intuition [12]. Metacognition has advantages in which the student tries to reflect the way of thinking or contemplating the cognitive processes it does.

Metacognition skill according to Flavell Is one's awareness of how one learns, the skill to judge the difficulty of a problem, the skill to observe the level of self-understanding, the skill to use information to achieve goals and the skill to assess self-learning progress [4]. The skill of metacognition is a person's skills in managing and controlling the thinking process. The metacognition skill indicator is based on NCREL that is: (a) developing a plan of action, (b) organize or monitor actions and (c) evaluate the action [4].

\subsection{Jigsaw Cooperatif Learning}

Cooperative learning model is a learning approach where students learn together as a team in completing group tasks to achieve shared goals. The cooperative learning model is structured in an effort to increase student participation, facilitate students with the experience of leadership attitudes and make decisions in groups, as well as provide opportunities 
for students to interact and learn together with students of different backgrounds.

Cooperative learning enables skills in working as teams, skills that are in dire demand in the workplace. Jigsaw is type of cooperative learning model in which each student becomes a member of two groups, namely the member of the home group and the member of the expert group so that students do not get bored because the discussions during the lesson they not only meet in one group [13].

Students can develop the positive relationships among his friends who have different capabilities, to help friends who have difficulty in understanding mathematical concepts and improve self-esteem of student [14].

Jigsaw learning method breaks away from the traditional structure based on memorization [15]. It introduces students to the logic of scientific research, as well as developing their capacity for continuing learning. Jigsaw type cooperative learning model more motivates students to work together to find something, grow mutual sense of team work, process information and improve high other thinking skills [16].

\section{METHODS}

This type of research is a qualitative descriptive study. This research is a type of research that aims to describe the creativity and metacognition of students in jigsaw cooperative learning. This research was conducted at SMP Methodist-An Pancur Batu in grade VIII in academic year 2018/2019, with a schedule that was coordinated with school activities carried out in July to December 2018.

In the research design the research steps can be described as follows: (1) field observations, (2) preparing research proposals, (3) validation and testing of learning tools and research instruments, (4) implementing learning with the Jigsaw cooperative learning model, (5) giving questionnaires to student responses and conducting tests, (6) conducting interviews as well as data triangulation, (7) data analysis and research findings, and (8) report writing.

The instruments in this study include: creative thinking skills test, students' metacognition ability tests, interview guidelines, and data triangulation. Interviews were conducted with directly selected subjects (face to face) between the researcher and the informants in a dialogical manner, questions and answers and discussions. The interview technique used is unstructured interviews. In accordance with this form of interview, researchers are not strictly tied to interview guidelines. The implementation can be carried out anywhere and at any time as long as it is related to the phenomenon and research focus. The type of interview used in this study is extensive and in-depth interviews.

Triangulation is a technique of checking the validity of data by utilizing something outside the data, for checking or as a comparison to that data [17]. The most widely used triangulation technique is checking through other sources. In connection with the triangulation, in this study triangulation functions to:
1) Comparing the results of research subject interviews with the answer sheet data on the test of creative thinking abilities and students' metacognition abilities.

2) Comparing the results of the teacher's interview with the caregiver with the answer sheet data about the test of creative thinking ability and student's metacognition ability.

Students are said to be complete in creative thinking if they get a test score $\geq 65$ scale of 100 . The interval criteria for creative thinking ability as in Table 2 below.

TABle 2. INTERVAl CRITERIA OF CREATIVE Thinking ABILITY

\begin{tabular}{|c|c|c|c|}
\hline No. & Score Interval & Rating Category & Ability Criteria \\
\hline 1. & $0 \leq \mathrm{SBKM}<45$ & very less & very low \\
\hline 2. & $45 \leq \mathrm{SBKM}<65$ & less & low \\
\hline 3. & $65 \leq \mathrm{SBKM}<80$ & enough & medium \\
\hline 4. & $80 \leq \mathrm{SBKM}<90$ & high & high \\
\hline 5. & $90 \leq \mathrm{SBKM}<100$ & very high & very high \\
\hline
\end{tabular}

Explanation : $\quad \mathrm{SBKM}=$ Mathematical Creative Thinking Score

In this study, to determine the difficulties of students in creative thinking based on the results of tests of creative thinking abilities (on each question) based on indicators: facts, concepts, principles, and procedures [18].

\section{RESUlT}

The purpose of this study is to obtain information about students' creative thinking abilities and metacognition with the application of Jigsaw cooperative learning. Based on the results of data analysis research results obtained as follows.

\subsection{Level of Students' Creative Thinking Ability}

After carrying out learning using the Jigsaw cooperative model on cube and beam material for 2 (two) meetings continued with tests on students to see students' creative thinking abilities. Based on the student answer sheets that have been corrected, the results obtained by the level of creative thinking abilities of students as in Table 3 below.

Table 3. Level of Students' Mathematical Creative Thinking ABILITY

\begin{tabular}{|c|c|c|c|c|}
\hline No & Interval Skor & $\begin{array}{c}\text { Sum of } \\
\text { Student }\end{array}$ & Persentage & $\begin{array}{c}\text { Rating } \\
\text { Category }\end{array}$ \\
\hline 1 & $0 \leq \mathrm{SBKM}<45$ & 6 & $15,79 \%$ & Very low \\
\hline 2 & $45 \leq \mathrm{SBKM}<65$ & 19 & $50,00 \%$ & low \\
\hline 3 & $65 \leq \mathrm{SBKM}<80$ & 7 & $18,42 \%$ & medium \\
\hline 4 & $80 \leq \mathrm{SBKM}<90$ & 4 & $10,53 \%$ & high \\
\hline 5 & $90 \leq \mathrm{SBKM}<100$ & 2 & $5,26 \%$ & Very high \\
\hline
\end{tabular}

Explanation: SBKM : Mathematical Creative Thinking Score

Based on the 38 students, it turns out that the level of creative thinking ability of low-ability students has the highest proportion, followed by medium-ability students. So, the level of creative thinking ability of students with very high abilities was $5.26 \%$, high abilities were $10.53 \%$, moderate abilities were $18.42 \%$, low abilities were $50.00 \%$, and very low abilities were $15.79 \%$. 


\subsection{Level of Students' Metacognition Ability}

After carrying out learning using the Jigsaw cooperative model on cube and beam material for 2 (two) meetings continued with the test of students to see the students' metacognition abilities. Based on the student answer sheets that have been corrected, the results obtained by the level of metacognition ability of students as in Table 4 below.

Table 4. LeVel of Students' Metacognition Ability

\begin{tabular}{|c|c|c|c|c|}
\hline No & Interval Skor & $\begin{array}{c}\text { Sum of } \\
\text { Student }\end{array}$ & Persentage & $\begin{array}{c}\text { Rating } \\
\text { Category }\end{array}$ \\
\hline 1 & $0 \leq \mathrm{SM}<45$ & 5 & $13,16 \%$ & Very low \\
\hline 2 & $45 \leq \mathrm{SM}<65$ & 27 & $71,05 \%$ & low \\
\hline 3 & $65 \leq \mathrm{SM}<80$ & 4 & $10,53 \%$ & medium \\
\hline 4 & $80 \leq \mathrm{SM}<90$ & 2 & $5,26 \%$ & high \\
\hline 5 & $90 \leq \mathrm{SM}<100$ & 0 & $0,00 \%$ & Very high \\
\hline
\end{tabular}

Explanation: $\mathrm{SM}=$ Metacognition Ability Score

Based on the 38 students, it turns out that the level of metacognition ability of high-ability students has the highest proportion, followed by very high-ability students. So, the level of metacognition ability of students with very high abilities was $0.00 \%$, high abilities were $5.26 \%$, moderate abilities were $10.53 \%$, low abilities were $71.05 \%$, and very low abilities were $13.16 \%$.

\subsection{Interview Implementation}

Conducting interviews with subjects conducted on students who meet the criteria. The criterion for taking the subject is to use 3 criteria which are based on indicators of student ability, error answers, and unique answers. Through the lens of indicators students' answer sheets are grouped into three categories of answers, namely (1) high ability student answer sheets; (2) medium ability student answer sheets; (3) low ability student answer sheets.

\subsubsection{Difficulty Analysis of Mathematical Creative Thinking Processes and Metacognition of Students with High Scores}

Students with high creative thinking skills have good awareness in several stages of metacognition. Based on the results of interviews obtained that: 1) Students do not experience the difficulty of facts, where students can understand and use appropriate symbols in representing mathematical problems. This can be seen from the mathematical models made by students right. 2) Students do not experience difficulties in understanding concepts, it appears that students are able to design mathematical models of the problems given correctly. Students also understand the principle of being able to apply the formula of surface area and volume appropriately. 3) Students also have no difficulty in mathematical procedures. This can be seen from the problem solving steps taken by the students in a series of ways and has done the calculation correctly.

Based on the triangulation of data obtained from the description of the answer sheets and the results of interviews on students in terms of subjects with high creative thinking score categories, the characteristics of thinking awareness of the two subjects are as follows: 1) Subjects are aware of their abilities, 2) Subjects generally know what it does, 3) The subject can provide arguments that support his thinking, and 4) The subject is able to provide an explanation to convince what is made.

Based on the characteristics listed above, then subjects with high creative thinking score categories are at the level of metacognition ability for strategic use.

\subsubsection{Difficulty Analysis of Mathematical Creative Thinking Processes and Metacognition of Students with Medium Scores}

Students with creative thinking skills are having a good awareness in several stages of metacognition. Based on the results of interviews obtained that: 1) Students do not experience the difficulty of facts, where students can understand and use appropriate symbols in representing mathematical problems. This can be seen from students being able to convert a given mathematical problem into a mathematical model. 2) Students do not experience difficulties in understanding concepts, it appears that students are able to design mathematical models of the problems given correctly. In terms of mathematical principles, students have difficulty in doing calculations in integer operations so that the problem solving done by students is not right. 3) Students experience difficulties in mathematical procedures. This can be seen from the inaccuracy of students in presenting problem solving so that the problem solving obtained is ineffective and inefficient.

Based on the triangulation of data obtained from the description of the answer sheets and the results of interviews with students in terms of the category of subjects with moderate creative thinking scores, the characteristics of the awareness of thinking of the two subjects are as follows: 1) Subjects are confused when reading and try to start to solve the problem, 2 ) The subject takes a decision against a certain reason, 3) The subject is aware of the weaknesses he has when solving problems, and 4) The subject begins to know what he doesn't know.

Based on the characteristics listed above, the subject with a score of creative thinking category is at the level of metacognition ability aware of use.

\subsubsection{Difficulty Analysis of Mathematical Creative Thinking Processes and Metacognition of Students with Low Scores}

Students with low problem solving skills have good awareness in several stages of metacognition. Based on the results of interviews obtained that: 1) Students have difficulty recognizing and understanding facts in mathematics that is difficulty in understanding the use of mathematical symbols. Students do not experience the difficulty of facts, where students can not understand and use appropriate symbols in representing mathematical problems. This can be seen when students cannot change a given mathematical problem into a mathematical model. 2) Students have difficulty in 
understanding concepts, it appears that students are not able to design mathematical models of the problems given correctly. Likewise in terms of mathematical principles, students have difficulty in doing calculations in integer operations so that the problem solving done by students is not right. 3) Students experience difficulties in mathematical procedures. This can be seen from the inaccuracy of students in presenting problem solving so that the problem solving obtained is ineffective and inefficient.

Based on the triangulation of data obtained from the description of the answer sheets and the results of interviews on subjects with low score creative thinking scores, the characteristics of thinking awareness of the two subjects are as follows: 1) Subjects provide explanations of problem solving uncertainly, 2) Subjects have confidence even though not aware of what he does not know, 3) The subject is not aware that the results obtained are not right (unaware of his weaknesses), 4) The subject does not know what he does not know, and 5) The subject also does not know that many reasons given are not meaningful .

Based on the characteristics listed above, the subjects with very low creative thinking scores are at the level of tacit use metacognition abilities.

\section{DISCUSSION}

This research focuses on analyzing the difficulties of students 'mathematical creative thinking processes and metacognition by basing one of the main objectives in learning that is training students' mathematical creative thinking and metacognition processes. In the Framework for Action it is written that ".... Education 2030 will ensure that all individuals acquire a solid foundation of knowledge, develop creative and critical thinking and collaborative skill and build curiosity, courage, resilience" [19]

In this study, habituation of students in mathematical creative thinking will also tend to open the broadest insight, so that mastery of the material is not only on the low aspect. This will start to leave ways of learning that are not quite right. as stated by Saragih and Habeahan that "... In fact the learning of mathematics in Indonesia tends to be limited to the mastery of the subject matter or relies on low-level cognitive aspects of development that are not able to develop the students' creativity" [20]. By accustomed to creative thinking, students are able to approach variously and have a variety of possible solutions to a problem, encourage the development of student creativity in line with the development of other aspects in order to create balance and harmony, giving rise to great satisfaction and pleasure [21].

Metacognition ability also becomes very important because it can train students' learning skills. Metacognition is thinking about thinking [22]. Metacognitive also relates to competencies about learning and thinking and solving problems. Metacognitive can also be interpreted by planning, monitoring and evaluation of what is learned [23]. Metacognition is the ability where the object of thinking is the thought process that occurs in oneself. As stated by Dawson that "Metacognitive skills are defined as interrelated competencies for learning and thinking, and consist of many skills required for effective learning, critical thinking, reflective judgment, problem solving, and decision making" [22].

In training and accustoming students' mathematical creative thinking processes, many methods are developed by teachers both through teaching material approaches, student uniqueness, and innovation that were originally discovered by themselves. In this study, learning using the Jigsaw Cooperative model is very helpful for students to plan completion so they are able to think creatively mathematically.

Jigsaw Cooperative Learning contributes to student development [24]. Jigsaw Cooperative Learning also suggests that teachers be facilitators [25]. In Jigsaw Cooperative learning, learning activities begin with the provision of authentic problems. In Jigsaw cooperative learning strategy, students tends to enjoy mathematics and this enjoyment motivates them to learn mathematics effectively [26].

Jigsaw learning is one of the learning patterns that gives rise to interactions between teachers and students and between students. In Jigsaw learning the interaction between teachers and students in learning mathematics is multidirection [16]. Jigsaw cooperative learning is an important strategy in improving self-concept in mathematics. Therefore it can be concluded that the jigsaw learning strategy can be used as a method of improving students' self-concepts especially in mathematical abilities [27]. Some of the results of these studies indicate that Jigsaw's cooperative learning can make students' creative thinking skills and metacognition better.

\section{CONCLUSION}

Based on the results of the students' mathematical creative thinking ability test, it was found that the very low category was $15.79 \%$, the low category was $50.00 \%$, the moderate category was $18.42 \%$, the high category was $10.53 \%$, the very high category was $5.26 \%$. While the results of the metacognitive ability test were obtained that the category was very low at $13.16 \%$, as low as $71.05 \%$, medium as much as $10.53 \%$, high as much as $5.26 \%$, and very high as $0.00 \%$.

Difficulties experienced by students in mathematical creative thinking are: i) Difficulty of facts, namely difficulties in representing mathematical symbols to design mathematical models of a given problem, ii) Difficulty of concepts, namely difficulties in applying the concept of surface area and volume of cubes and beams, iii) Difficulties of principle, i.e. difficulties in applying mathematical formulas and rules as well as difficulties in connecting given concepts, and iv) Difficulties in procedures, namely difficulty in presenting problem solving steps in a series and correct, inaccuracy in the presentation problem solving, as well as difficulties in devising problem solving strategies effectively and efficiently. 


\section{REFERENCES}

[1] Hasratuddin. 2015. Mengapa Harus Belajar Matematika? Medan Perdana Publishing.

[2] Fardah, K. D. 2012. Analisis Proses dan Kemampuan Berpikir Kreatif Siswa dalam Matematika Melalui Tugas Open-Ended. Jurnal Kreano, $3(2)$

[3] Jayapraba, G. 2013. Metacognitive Instruction and Cooperative Learning-Strategies For Promoting Insightful Learning In Science. Research Scholar. University Tirunelveli India. International Journal on New Trends in Education and Their Implications, 4(15): 165-172.

[4] Mustafa., Sinaga, B., Asmin. 2017. Development of Learning Devices Through Problem Based Learning Model to Improve Students Metacognition Skill at SMPN 17 Medan. Journal Education and Practice. 8(24): 34-41.

[5] Lie, A. 2011. Coopertive Learning. Jakarta: Grasindo

[6] Nasution, F. K. W., Sinaga, B., Mulyono. 2017. Development of Learning Devices Based on Contextual Teaching and Learning to Improve Students' Creativity Mathematics at SMPN 1 Padangsidimpuan. IOSR Journal of Research \& Method in Education (IOSR-JRME), 7(6): 61-68

[7] Wang, Y.A. 2011. Contexts of Creative Thinking: A Comparison on Creative Performance of Student Teachers in Taiwan and the United States. Journal of International and Cross-Cultural Studies, 2(1):1-14.

[8] Mawaddah, N. E., dkk. 2015. Model Pembelajaran Discovery Learning dengan Pendekatan Metakognitif Untuk Meningkatkan Metakognisi dan Kemampuan Berpikir Kreatif Matematis. Unnes Journal of Mathematics Education Research, 4(1): 10-17.

[9] Livingston, J. A. 2003. Metacognition : An Overview. New York: ERIC Clearinghouse on Urban Education

[10] Papaleontiou-Louca, E. 2003. The Concept and Instruction of Metacognition. Teacher Development, 7(1) : 9-30.

[11] Jayapraba, G. (2013). Metacognitive Instruction and Cooperative Learning-Strategies For Promoting Insightful Learning In Science. Research Scholar. University Tirunelveli India. International Journal on New Trends in Education and Their Implications, 4(15): 65-172.

[12] Schoenfeld. 1992. Learning to Think Mathematically: Problem Solving, Metacognition, and Sense Making in Mathematics. Handbook of Research on Mathematics Teaching and Learning. New York: Macmillan Publishing Company.

[13] Sitinjak, A. A., \& Mawengkang, H. 2018. The Difference of Students' Mathematical Achievement By Using Guided-Discovery And Cooperative Learning Model Jigsaw Type. Infinity: Journal of Mathematics Education, 7(1): 45-54.
[14] Sari, D. M. (2017). Analysis of Students'mathematical Communication Ability by using Cooperative Learning Talking Stick Type. Infinity Journal, 6(2): 183-194.

[15] Chu, S. (2014). Aplication of the Jigsaw Cooperatif Learning Method in Economic Course. International Journal of Managerial Studies and Research, 10(2): 166-172.

[16] Pakhrurrozi, I., Sujadi, I., Pramudya, I. (2018). Analysis of Interaction Jigsaw Learning Process on Geometry Material. International Journal of Multicultural and Multireligious Understanding, 5(5):75-79.

[17] Moleong. 2012. Metodologi Penelitian Kualitatif. Bandung: Remaja Rosdakarya.

[18] Wulandari., Sinaga, B., Minarni, A. 2017. Analysis of Students Metacognition Ability in Mathematical Problem Solving on Problem Based Learning in SMA Negeri 1 Binjai. IOSR Journal of Research \& Method in Education (IOSR-JRME), 8(1): 32-40.

[19] Framework for Action. 2016. Education 2030 Incheon Declaration and Framework for Action. Republic of Korea: Unesco.

[20] Saragih, S., Habeahan, W,L. 2014. The Improving of Problem Solving Ability and Students' Creativity Mathematical by Using Problem Based Learning in SMP Negeri 2 Siantar. Journal of Education and Practice, 5 (35): 123-133.

[21] Sophonhiranraka, S., Suwannatthachoteb, P., Ngudgratokec, S. 2014 Factor Affecting Creative Problem Solving in the Blended Learning Envoronment: a review of the literature. Thailand: Elsevier LTd.

[22] Aljaberi, N.M \& Eman Gheith. 2015. University Student's Level of Metacognition Thinking and their Ability to Solve Problems. American International Journal of Contemporary Research, 5(3): 121-134

[23] Sengul, S., Katranci, Y. 2015. Meta-cognitive Aspects of Solving Indefinite Integral Problems. Elsevier, Procedia Social and Behavioral Sciences, 197: 622-629.

[24] Tan, C. P., Molen, V.D., Schmidt, H.G. 2015. To What Extent does Problem Based Learning Contribute to Students' Professional Identity Development?. Singapore: Elsevier LTd.

[25] William, J.C., \& Paltridge, D.J. 2016. What We Think We Know About the Tutor in Problem Based Learning. Australia: Elsevier LTd.

[26] Venkateshwar, R, D. (2016). Understanding Jigsaw Cooperative Learning: Influence on Scholastic Achievement and Learning Experiences of Students in Mathematics Education. The International Journal of Indian Psychology, 3(3): 100-106.

[27] Mbacho, N.W., dan Mwebi, R. 2017. Jigsaw Cooperative Learning Strategy And Students' Self-Concept In Mathematics. International Journal of Social Science and Economic Research, 1(9): 1317-1332. 